\title{
Task-based Instruction
}

\author{
Keivan Seyyedi (Corresponding author) \\ School of Educational Studies Universiti Sains Malaysia \\ PO Code 11800, Penang, Malaysia
}

Tel: 60-142-495-710Ｅ-mail: kevansayyedi@yahoo.com

\author{
Shaik Abdul Malik Mohamed Ismail \\ School of Educational Studies, Universiti Sains Malaysia \\ PO Code 11800, Penang, Malaysia
}

Tel: 60-134-128-211Ｅ-mail: samalik@usm.my

Received: June 1, 2012 Accepted: June 19, 2012 Published: September 1, 2012

doi:10.5296/ijl.v4i3.2203 URL: http://dx.doi.org/10.5296/ijl.v4i3.2203

\begin{abstract}
Task-based is a kind of instruction in which language learners, performing activities, are engaged in meaningful, goal-oriented communication to solve problems, complete projects, and reach decisions. Tasks have been used for a broad range of instructional purposes, serving, for example, as units of syllabuses, activities for structure or function practice, and language focusing enhancements to content-based curricula. In this literature, some issues related to task-based instruction will be discussed.
\end{abstract}

Keywords: Analytic syllabus, Synthetic syllabus, Task-based language teaching, Complexity, Fluency, Accuracy 


\section{Introduction}

In the last two decades second and foreign language has become more and more characterized by the communicative approach to language teaching and learning, whose main objective is "to develop the learner's ability to take part in spontaneous and meaningful communication in different contexts, with different people, on different topics, for different purposes" (Celce-Murcia, Dörnyei, and Thurrell, 1997, p. 149). Task-based instruction is a new approach within this framework, which calls for language teaching to be organized around different tasks (Long, and Crookes, 1992; Skehan, 1998; Willis, and Willis, 2001).

\section{Task-based Syllabus}

Among the analytic syllabuses, those which have been the center of attention to many scholars since 1970s are task-based syllabuses. Task-based approaches to second language teaching focus on the learner's ability to perform target-like tasks without any explicit instruction of grammatical rules (Rahimpour, 2008) and include procedural syllabuses, process syllabuses and task based language teaching (TBLT) (Long and Crookes, 1992). In this type of syllabuses, learners control their own learning.

TBLT owes its development to the dissatisfaction with the former language teaching methods such as, grammar translation, direct method, audiolingualism and etc. Rahimpour (2008) asserts that TBLT is a response to a better understanding of a language learning process. In this approach, task is considered as a unit of analysis and emphasizes on meaning without any prior attention to forms. Thus, learners can use any strategies to perform the task and achieve the task goal (Willis and Willis, 2001).

However, many scholars criticized TBLT and arguing that if no focus on form is encouraged while performing a task, learners will develop a very low level of language proficiency (Nunan, 2004; Skehan, 2003; Willis and Willis, 2001).

\section{What is a Task?}

There exist so many definitions of a task in the literature. We refer to some in the following:

Richards and Renandya (2002, p. 94), give the following definition:

"A task is an activity which learners carry out using their available language resources and leading to a real outcome. Examples of tasks are playing a game, solving a problem or sharing and comparing experiences. In carrying out tasks, learners are said to take part in such processes as negotiation of meaning, paraphrase and experimentation, which are thought to lead to successful language development."

According to Widdowson (2003, p. 124) Skehan provided the most comprehensive theoretical rationale for the task-based learning, so it seems reasonable to take his definition as having some authority. Skehan regarded a task as an activity which satisfies the following criteria:

- Meaning is primary; 
- there is some communication problem to solve;

- there is some sort of relationship to comparable real-world activities;

- task completion has some priority;

- The assessment of task in terms of outcome (Skehan 1998, p. 95).

However, as Bygate (2001) noted, Skehan's definition is incomplete in a number of respects. Apart from the ideas of the primacy of meaning, the existence of an objective, and the possibility of assessment, there is the fact that tasks are susceptible to pedagogic intervention as well as the idea that tasks can be influenced by learner choice and can be potentially reinterpreted by learners.

Nunan (2004) makes a distinction between what is called a real-world or target task (uses of language in real life) and a pedagogic task (what the learners do in class). He further argues that tasks differ from other kinds of activities in that they have a non-linguistic outcome, e.g., painting a fence, dressing a child and etc.

Nunan (2004, p. 4) then goes on defining a task as follows:

"A piece of classroom work that involves learners in comprehending, manipulating, producing or interacting in the target language while their attention is focused on mobilizing their grammatical knowledge in order to express meaning and in which the intention is to convey meaning rather than to manipulate form. The task should also have a sense of completeness, being able to stand alone as a communicative act in its own right with a beginning, middle and an end."

\section{Rationale for Task-based Language Teaching (TBLT)}

TBLT focuses on the ability to perform a task or activity without explicit teaching of grammatical structure (Rahimpour, 2008). It is argued that such an approach creates more favorable and better conditions for the development of second language ability than does an approach that focuses solely on the explicit teaching and learning of the rules of the language (Long, 1985; Prabhu, 1987; Robinson, 2001b).

The rationale for TBT comes from different camps; Ellis (2003) provided psycholinguistic rationale, whereas, Skehan (1998, 2003, 2009b) and Robinson (2001a, 2007b, 2011), took a more cognitive approach to advocate it. Skehan (1998, p. 95) pointed out that "as an approach to instruction, TBT is theoretically defensible and practically feasible. The assumption here, then, is the fact that transacting tasks will engage naturalistic acquisitional mechanisms, cause the underlying interlanguage system to be stretched, and drive development forward."

Ellis (2003) listed three arguments in favor of task-based syllabuses. First, it is based on the theoretical view that instruction needs to be compatible with the cognitive processes involved in L2 acquisition. Second, the importance of learner 'engagement' is emphasized. Third, tasks serve as a suitable unit for specifying learners' needs and thus for designing specific purpose courses. 
In line with the cognitive approaches to language learning, Robinson (2003b) argues that task-based pedagogy can facilitate the cognitive processes involved in second language production (performance) and acquisition (development), and their relationship. Similarly, Prabhu (1987) views language development as the result of natural processes and argues against focus on language form as inhibiting language learning.

One of the main advantages of task-based instruction is that well-designed tasks facilitate noticing of L2 syntax, vocabulary, and phonology that may lack perceptual and psychological saliency in untutored conversational settings and so may go unnoticed and unlearned (Schmidt, 1990).

The best documented application of a task-based approach is probably Prabhu's procedural syllabus (Willis and Willis, 2001). The Bangalore project, the communicative teaching project, took place from 1979 to 1984 and was based mainly on the premise that language form can be learnt in the classroom solely through a focus on meaning, and that grammar construction by the learner is an unconscious process (Prabhu, 1987).

\section{Tasks in Second Language Acquisition (SLA) Research}

SLA research history can be divided into two stages (Ellis, 2003). In the first stage, which initiated in the late sixties and seventies, researchers tended to describe how an L2 is acquired. An example of this is the documentation of the sequence in which the grammar of a language was acquired. The main goal of this stage was to examine how learners acquired an L2 naturalistically. In the second stage, SLA became more theory-oriented as researchers started testing specific hypotheses based on theories of L2 acquisition. Tasks were present in both SLA research stages, and have also become a focus of research in their own right (Ellis, 2003, 2005; Skehan, 2003).

Skehan (2003) distinguishes four research-oriented approaches to tasks: a psycholinguistic approach to interaction; a social interactive approach; a concern for structure-focused tasks; and a cognitive perspective. In the following, I will shed light on each of these approaches.

\subsection{A Psycholinguistic Approach to Interaction}

This approach, which was initiated in the eighties, represents the first major research area to emerge into task-based instruction. It was heavily influenced by the work of Krashen (1981, 1985, 1994) and Long (1983). Krashen has advanced the Input Hypothesis which claims that language acquisition relies on learners' ability to comprehend the input they are exposed to. Thus, according to Krashen, language acquisition is input-driven.

Long's Interaction Hypothesis, which is based on negotiation of meaning, also emphasizes on input, but through interaction. Negotiation of meaning is viewed as a process that "provides learners with opportunities for both the provision of comprehensible input and the production of modified output" (Shehadeh, 2005, p. 21). Long proposes that interactional modifications made by learners induce their interlocutors to change their input.

More recently, Long (1996) suggested that negotiation of meaning also contributes to acquisition through negative feedback. Therefore, he proposed that tasks which lead to 
beneficial negotiation of meaning are indexed by greater numbers of comprehension checks, clarification requests, and confirmation checks.

These Hypotheses have led researchers to utilize tasks to investigate which kind of input works best for comprehension and language acquisition, and, more recently, the effect of negative feedback on acquisition (Ellis, 2003). They have also motivated cognitive-oriented research that focused on identifying the psychologically motivated task characteristics that affect the nature of language production (Crookes, 1986).

\subsection{A Sociocultural Approach to Interaction}

The sociocultural approach to interaction views interaction from the viewpoint of the sociocultural theory which proposes that knowledge is a joint activity that is constructed by learners collaboratively (Shehadeh, 2005). That is, there is no particular concern with negotiation of meaning in terms of what happens when there is a conversational breakdown and the role of feedback at such points, but rather an interest in how participants shape tasks to meet their own ends and how they collaboratively build meanings that are unpredictable and personal, and which contribute to L2 learning (Skehan, 2003).

Within this area, there are different, often overlapping, approaches. One approach concerns the way tasks are reinterpreted by learners to respond to their individual interests (Duff, 1993). Therefore, the interest is in how learners approach a task rather the properties of the task itself. Another approach concerns the potential of different tasks to enable language understanding to be scaffolded by participants, mutually, through interaction (Swain and Lapkin, 2001). That is, "learners first succeed in performing a new function with the assistance of another person and then internalize this function so that they can perform it unassisted" (Ellis, 2000, p. 209). A third concerns the nature of interaction itself (Van Lier and Matsuo, 2000).

\subsection{Structure-focused Tasks}

More recently, the generalization about negotiation of meaning has been modified so that within the use of tasks, there should be a focus on form. This means that even in interactions with meaning as primary, there should be concern for form (Skehan, 2003). Many studies have demonstrated that task procedures can be changed in a way as to induce the use of specific features of language (Ellis, 2003). These are called focused tasks. In this regard three kinds of tasks are recognized: structure based production tasks; comprehension tasks; and conscious-raising tasks (Skehan, 2003).

In the first category, Newton and Kennedy (1996) found that it is possible to predict the linguistic forms that will be used when particular tasks are performed. In the same vein, Mackey (1999) reports on a task designed to elicit question forms. According to Mackey, the task was successful with some effort on the part of learners in leading to greater production of questions. As to comprehension-based tasks, input enhancement tasks, such as those used in Doughty (1991), as well as input processing tasks, such as those used in Bygate (1999) were found to have positive effects on performance. Other studies have investigated conscious-raising tasks, and have found positive effects. For example, Fotos and Ellis (1991) 
and Fotos (1994) found that conscious raising tasks led to a good understanding of target grammatical points when compared with performance resulting from traditional grammatical explanation provided by the teacher, and resulted in negotiation of meaning that is comparable to unfocused tasks.

\subsection{A Cognitive Perspective}

This approach is mainly concerned with the psychological processes learners engage in when performing a task. Researchers adopting this approach have investigated three main areas: analyses of how attentional resources are used during task completion; the influence of task characteristics on performance; and the effect of different conditions under which tasks are completed (Skehan, 2003).

As to attentional resources, there exist two conflicting theories regarding how human mind works while performing a task. The first and the widely accepted approach is Skehan and Foster's (2001) Limited Attentional Capacity Model which argues that language learners possess a limited processing capacity, so that there exist trade-offs between the three aspects of language production, namely complexity, accuracy and fluency (CAF). That is, it is not possible to achieve these aspects of performance simultaneously. As a consequence, language learners have to prioritize which aspect to achieve.

The next theory proposed by Robinson (2001a, 2007b) isn't in line with Skehan's (1998) predictions. Robinson (2001a, 2007b) drawing on more recent work in psychology (Neumann, 1996), concluded that human attention is not limited, and that learners are able to attend to more than one aspect of language simultaneously. According to this view, the structural and functional complexities are connected rather than competing with each other. Robinson also determines task complexity by two features of resource directing (e.g., whether or not the task requires reasoning) and resource dispersing (e.g., whether or not there is opportunity for strategic planning). In this model, strategic planning is as resource dispersing factor which interact with resource directing factors to determine the complexity of the task and the extent to which learners attend to form while performing the task, resulting in increased fluency but decreased accuracy and complexity (Ellis, 2005, p. 16). Clearly, much more research will have to be undertaken before we are in a position to say which of these competing models is the most convincing.

Research investigating the effects of task characteristics has sought to examine the effects of different task characteristics including structured tasks (i.e. clear time line or macro-structure), familiar information, outcomes requiring justifications, and interactive vs. monologic tasks on language production. The generalization made through findings indicates that while task choice hardly guarantees focus on particular aspects of language (CAF), there is some predictability involved. In other words, learners can be engaged in a variety of tasks depending on the aspect of language that is to be developed. Thus, if the aim is to promote fluency, learners should be engaged in tasks that are meaning-oriented. However, if the aim is to enhance complexity and/or accuracy, the tasks should be form-oriented. 


\section{Macrothink Institute ${ }^{\mathrm{TM}}$}

Finally, research on the effect of different task conditions on language performance has been the most active area in task research (Skehan, 2003). One line of research in this area has investigated the effects of strategic planning (Ellis and Yuan, 2004; Kawauchi, 2005; Yuan and Ellis, 2003), task repetition (Gass, Mackey, Alvarez-Torres, and Fernandez-Garcia, 1999), and post-task activities (Skehan and Foster, 1997) on language production.

\section{References}

BIBLIOGRAPHY \l 1033 Celce-Murcia, M., Dörnyei, Z., \& Thurrell, S. (1997). Direct approaches in L2 instruction: A turning point in communicative language teaching? TESOL Quarterly, 31(1), 141-152.

Bygate, M. (1999). Quality of language and purpose of task: Patterns of learners' language on two oral communication tasks. Language Teaching Research, 3(3), 185-214. http://dx.doi.org/10.1177/136216889900300302.

Bygate, M., Skehan, P., \& Swain, M. (2001). Researching pedagogic tasks: Second language learning, teaching and testing. New York: Longman.

Crookes, G. (1989). Planning and interlanguage variation. Studies in Second Language Acquisition, 11, 367-383.

Doughty, C. (1991). Second language instruction does make a difference: Evidence from an empirical study on SL revitalization. Studies in Second Language Acquisition, 13, 431-69.

Duff, P. (1993). Tasks and interlanguage performance: an SLA perspective. In G. Crookes, \& s. Gass (Ed.), Tasks and language learning: Integrating theory and practice. Clevedon, Avon: Multilingual Matters.

Ellis, R. (2000). Task-based research and language pedagogy. Language Teaching Research, 4, 193-220. http://dx.doi.org/10.1177/136216880000400302.

Ellis, R. (2003). Task-based language learning and teaching. Oxford: Oxford University Press.

Ellis, R. (2005). Planning and task performance in a second language. Amesterdam: Benjamins.

Ellis, R., \& Yuan, F. (2004). The effects of planning on fluency, complexity, and accuracy in second language narrative writing. Studies in Second Language Acquisition, 26, 59-84.

Fotos, S. (1994). Integrating grammar instruction and communicative language use through grammar consciousness-raising tasks.

Fotos, S., \& Ellis, R. (1991). Communicating about grammar: A task-based approach. TESOL Quarterly, 25, 605-628.

Gass, S., Mackey, A., Alvarez-Torres, M. J., \& Fernandez-Garcia, M. (1999). The effects of task repetition on linguistic output. Language Learning, 49(4), 549-581. http://dx.doi.org/10.1111/0023-8333.00102. 
Kawauchi, C. (2005). The effects of strategic planning on the oral narratives of learners with low and high intermediate L2 proficiency. In R. Ellis (Ed.), Planning and task performance in a second languages (pp. 239 - 277). Amsterdam: John Benjamins.

Krashen, S. (1981). Second language acquisition and second language learning. Oxford: Pergamon.

Krashen, S. (1985). The input hypothesis: Issues and implications. Oxford: Longman.

Krashen, S. (1994). The input hypothesis and its rivals. In N. C. Ellis (Ed.), Implicit and explicit learning of languages (pp. 45-77). London: Academic Press.

Long, M. H. (1983). Native speaker/non-native speaker conversation and the negotiation of comprehensible input. Applied Linguistics, 4, 126-141. http://dx.doi.org/10.1093/applin/4.2.126.

Long, M. H. (1985). A role for instruction in second language acquisition: Task-based language teaching. In K. Hyltenstam, \& M. Pienemann (Eds.), Modeling and accessing second language acquisition (pp. 77-99). Clevedon: Multilingual Matters.

Long, M. H. (1996). The role of linguistic environment in second language acquisition. In W. C. Ritchie, \& T. K. Bhatia (Eds.), Handbook of second language acquisition (pp. 413-463). San Diego: Academic Press.

Long, M. H., \& Crookes, G. (1992). Three approaches to task-based syllabus design. TESOL Quarterly, 26(1), 27-56.

Mackey, A. (1999). Input, interaction, and second language development: An empirical study of question formation in ESL. Studies in Second Language Acquisition, 21, 557-587.

Neumann, O. (1996). Theories of attention. In O. Neumann, \& A. Sanders (Eds.), Handbook of perception and action (Vol. 3: Attention, pp. 389-446). San Diego: Academic Press.

Newton, J., \& Kennedy, G. (1996). Effects of communication tasks on the grammatical relations marked by second language learners. System, 24(3), 309-322. http://dx.doi.org/10.1016/0346-251X(96)00024-3.

Nunan, D. (2004). Task-based language teaching. Cambridge: Cambridge University Press.

Prabhu, N. S. (1987). Second language pedagogy. Oxford: Oxford university press.

Rahimpour, M. (2008). Implementation of task- based approaches to language teaching. Research on Foreign Languages Journal of Faculty of Letters and Humanities, 41, 45-61.

Richards, J. C., \& Schmidt, R. (2002). Longman dictionary of language teaching and applied linguistics (3rd ed.). London: Pearson Education Limited.

Robinson, P. (2001a). Task complexity, cognitive resources, and syllabus design: A triadic framework for investigating task influences on SLA. In P. Robinson (Ed.), Cognition and second language instruction (pp. 287-318). Cambridge: Cambridge University Press. 
Robinson, P. (2001b). Task complexity, task difficulty, and task production: Exploring interactions in a componential framework. Applied Linguistics, 27-57. http://dx.doi.org/10.1093/applin/22.1.27.

Robinson, P. (2003b). The Cognition Hypothesis, task design and adult task-based language learning. Second Language Studies, 21(2), 45-107.

Robinson, P. (2007b). Criteria for grading and sequencing pedagogical tasks. In M. P. Garcia Mayo (Ed.), Investigating tasks in formal language learning (pp. 7-27). Clevedon, UK: Multilingual Matters.

Robinson, P. (2011). Task-based language learning: A review of issues. Language Learning, 61, 1-36. http://dx.doi.org/10.1111/j.1467-9922.2011.00641.x.

Schmidt, R. W. (1990). The role of consciousness in second language learning. Applied linguistics, 11(2), 17-46.

Shehadeh, A. (2005). Task-based language learning and teaching: Theories and applications. In C. Edwards, \& J. Willis (Eds.), Teachers Exploring Tasks in English Language Teaching (pp. 13-30). U.K.: Palgrave Macmillan.

Skehan, P. (1998). A cognitive approach to language learning. Oxford: Oxford University Press.

Skehan, P. (2003). Task-based instruction. Language Teaching, 36, 1-14. http://dx.doi.org/10.1017/S026144480200188X.

Skehan, P. (2009b). Models of speaking and the assessment of second language proficiency. In A. Benati (Ed.), Issues in second language proficiency (pp. 203-215). London: Continuum.

Skehan, P., \& Foster, P. (1997). Task type and task processing conditions as influences on foreign language performance. Language Teaching Research, 1(3), 185-211. http://dx.doi.org/10.1177/136216889700100302.

Skehan, P., \& Foster, P. (2001). Cognition and tasks. In P. Robinson, Cognition and second language instruction (pp. 183-205). Cambridge: Cambridge University Press.

Swain, M., \& Lapkin, S. (2001). Focus on form through collaborative dialogue: exploring task effects. In M. Bygate, P. Skehan, \& M. Swain (Eds.), Researching pedagogic tasks, second language learning, teaching, and testing (pp. 99-118). New York: Longman.

van Lier, L., \& Matsuo, N. (2000). Varieties of conversational experience: looking for learning opportunities. Applied Language Learning, 11(2), 265-287.

Widdowson, H. G. (2003). Defining issues in English language teaching. Oxford: Oxford University Press. 


\section{Macrothink}

International Journal of Linguistics

ISSN 1948-5425 2012, Vol. 4, No. 3

Willis, D., \& Willis, J. (2001). Task-based language learning. In R. Carter, \& D. Nunan, The Cambridge guide to teaching English to speakers of other languages (pp. 173-179). Cambridge: Cambridge University Press.

Yuan, F., \& Ellis, R. (2003). The effect of pre-task planning and on-line planning on fluency and complexity and accuracy in L2 monologic oral production. Applied Linguistics, 24(1), 1-27. http://dx.doi.org/10.1093/applin/24.1.1. 